Tropical Journal of Pharmaceutical Research March 2019; 18 (3): 513-518

ISSN: 1596-5996 (print); 1596-9827 (electronic)

(C) Pharmacotherapy Group, Faculty of Pharmacy, University of Benin, Benin City, 300001 Nigeria.

\title{
Cavidine protects against asthma in neonatal asthmatic mice model by attenuating PI3Ks/NF-kB signaling pathway
}

\author{
Qin Hao, Juan Shen, Lin Zhao* \\ Department of Pediatric Nursing Teaching and Research, Medical College of Yan'an University, Shaanxi 716000, China \\ ${ }^{*}$ For correspondence: Email: VApriloelm@yahoo.com; Tel: +86 9112412293
}

Sent for review: 3 September 2018

Revised accepted: 15 February 2019

\begin{abstract}
Purpose: To evaluate the protective effect of cavidine against asthma in neonatal mice.

Methods: Neonatal mice were treated with cavidine at doses of 5 and $10 \mathrm{mg} / \mathrm{kg}, \mathrm{po}, 2 \mathrm{~h}$ prior to asthma induction with ovalbumin (OVA) on the 1st and 14th days of the treatment protocol. The anti-asthma activity of cavidine was evaluated by determining the number of inflammatory cells and cytokine levels in broncho-alveolar lavage fluid (BALF) and OVA-specific IgE and TGF- $\beta 1$ in the serum of OVAsensitized mice. The levels of NF-KB and PI3K protein expression were determined in the lung tissues of OVA-sensitized mice.

Results: Cavidine attenuated the number of inflammatory cells and cytokines in BALF of OVAsensitized mice. The levels of OVA-specific IgE and TGF- $\beta 1$ decreased significantly in cavidine-treated groups, when compared to asthmatic group of mice, while NF-kB was significantly downregulated ( $p<$ 0.01). The altered expression of PI3K signaling protein was attenuated in the lung tissues of cavidinetreated mice sensitized with OVA.

Conclusion: These results reveal that the anti-asthma effect of cavidine in OVA-induced asthmatic neonatal mice occurs via reduction of inflammation and immune responsive cells linked to PI3Ks/ NF-KB signaling pathway in lung tissues. These findings suggest that cavidine may be clinically suitable for the management of asthma.
\end{abstract}

Keywords: Cavidine, Asthma, Inflammation, Immune cell, Neonatal, PI3K signaling

\begin{abstract}
This is an Open Access article that uses a funding model which does not charge readers or their institutions for access and distributed under the terms of the Creative Commons Attribution License (http://creativecommons.org/licenses/by/4.0) and the Budapest Open Access Initiative (http://www.budapestopenaccessinitiative.org/read), which permit unrestricted use, distribution, and reproduction in any medium, provided the original work is properly credited.

Tropical Journal of Pharmaceutical Research is indexed by Science Citation Index (SciSearch), Scopus, International Pharmaceutical Abstract, Chemical Abstracts, Embase, Index Copernicus, EBSCO, African Index Medicus, JournalSeek, Journal Citation Reports/Science Edition, Directory of Open Access Journals (DOAJ), African Journal Online, Bioline International, Open-J-Gate and Pharmacy Abstracts
\end{abstract}

\section{INTRODUCTION}

Asthma is an inflammatory lung disorder characterized by infiltration of neutrophils, lymphocytes and macrophages in the lung tissues [1]. The pathogenesis of asthma involves increased secretion of mucus, hyperresponsiveness and remodeling of the airways [2]. Cytokines are responsible for remodeling and inflammation of airways which is activated by $T$ lymphocytes [3]. Cytokines trigger the release of immunoglobulin $\mathrm{E}$, leading to the release of inflammatory mediators by mast cells [4]. Thus, the determination of cytokine levels is an important step for assessing asthma. The enzyme PI3K controls cell signaling, proliferation and differentiation of cells [5]. Moreover, Akt protein is activated by $\mathrm{PI} 3 \mathrm{~K}$ which acts on mammalian targets of rapamycin and glycogen synthase kinase $3 \mathrm{~b}$ [6]. In T cells, activation of 
PI3K results in progression, survival and differentiation of cells [7]. Several natural compounds have shown promising potential in the management of asthma and other chronic disorders. Cavidine is an alkaloid isolated from Corydalis impatiens [8]. Corydalis impatiens is a Chinese herb traditionally used for the management of cholecystitis, hepatitis and skin injuries [9]. Studies have revealed that cavidine has promising effects against gastric ulcer, colitis and inflammation $[10,11]$. These effects of cavidine depend on its antioxidant and antiinflammatory properties [12]. Cavidine shows anti-inflammatory activity by attenuating the NF$\mathrm{KB}$ signaling pathway and pro inflammatory cytokines [11]. The present study was aimed at investigation the protective effect of cavidine against asthma in OVA-sensitized mice model.

\section{EXPERIMENTAL}

\section{Animals}

BALB/c mice were purchased from Dashuo Laboratory Animal Reproduction Center, China. They were maintained under standard conditions (12-h day/12-h night light cycle, $60-80 \%$ humidity and temperature of $26 \pm 1^{\circ} \mathrm{C}$ as per the guidelines of the Association for the Assessment and Accreditation of Laboratory Animal Care International (AAALAC) [13]. The pups were monitored carefully from the day of litter (day 1 (P1). All the protocols used were approved by Institutional Animal Care and Use Committee of Medical College of Yan'an University, China (no. IACUC/YU/2017/03).

\section{Induction of asthma}

Mice at 12 days of age (P12) were used for the induction of asthma and were divided into five different groups: normal group, asthmatic group, cavidine (5 and $10 \mathrm{mg} / \mathrm{kg}$ ) groups, and STD group. The mice were sensitized with intraperitoneal administration of OVA $(20 \mu \mathrm{g})$ on day 1 and $14^{\text {th }}$ day, and from the $22^{\text {nd }}$ to $24^{\text {th }}$ days, the animals were treated for 30 min with $1 \%$ OVA aerosol. The cavidine groups were treated with cavidine at 5 and $10 \mathrm{mg} / \mathrm{kg} \mathrm{p.o.} 2 \mathrm{~h}$ prior to OVA challenge on the $1^{\text {st }}$ and $14^{\text {th }}$ days. The STD group received intraperitoneal administration of Dexomethasone Dex $(2 \mathrm{mg} / \mathrm{kg}$ ) $60 \mathrm{~min}$ prior to administration of OVA.

\section{Assessment of serum and broncho-alveolar lavage fluid (BALF)}

Tracheotomy was performed at the end of treatment protocol with cervical dislocation, and BALF was collected from the isolated lung. A hemocytometer was used to determine the quantity of inflammatory cells in the BALF, while Wright's staining was used to estimate differential cell count. The serum levels of OVAspecific $\lg E$ and TGF- $\beta 1$ in BALF were assayed with ELISA kits as per the manufacturer's instructions.

\section{Assessment of inflammatory cytokines in BALF}

ELISA kits were used for the assessment of BALF contents of cytokines such as IL-17, IL-13, IL-6, IL-4 and IFN-y as per the instruction of the kit manufacturer.

\section{Histopathological studies}

Lung tissues were isolated from each animal and fixed in $10 \%$ formalin solution. The tissues were paraffin wax-embedded and a microtome was used to section them into 5-mm thick slices which were stained with hematoxylin andeosin (H\&E). Leucocyte infiltration was scored by the cell count: no cells, few cells, ring of cells 1 cell layer deep, ring of cells $2-4$ cell layers deep, and ring of cells 4 cell layers deep were scored $0,1,2,3$ and 4 , respectively.

\section{Assessment of activity of NF-KB}

Lung tissue was homogenized in saline solution and centrifuged at $2000 \mathrm{rpm}$ for $10 \mathrm{~min}$. ELISA kits were used to determine the levels of $p-\mid k B \alpha$, I $k \alpha \alpha, p-N F-k B$ p65 and NF-kB p65 in the supernatant solution as per the manufacturer's instruction.

\section{Western blot assay}

Lysis buffer containing protease inhibitor was incubated with isolated CD4+ T cells, and protein assay kit was used to determine the concentration of protein in the lysate. The isolated protein was subjected to SDSpolyacrylamide gel electrophoresis, and the fractions were transferred to nitrocellulose membranes and incubated at $4^{\circ} \mathrm{C}$ overnight with primary antibodies for Notch-1, PTEN mTORc1, $\mathrm{p}$-Akt, Akt and $\beta$-actin. Thereafter, peroxidaseconjugated secondary antibodies were incubated with isolated proteins for $1 \mathrm{~h}$ at room temperature, and the densities of the bands were determined using chemiluminescence.

\section{Statistical analysis}

Data are expressed as mean \pm SEM $(n=10)$. Statistical analysis was performed using one-way ANOVA. Post-hoc comparison of means was 
carried out by Dunnett's post hoc test for multiple comparisons. The level of statistical significance was set at $p<0.05$.

\section{RESULTS}

\section{Cavidine attenuated the altered levels of inflammatory cells}

Figure 1 shows the effect of cavidine on cellular inflammation in OVA-sensitized mice. There was an increase in inflammatory cells such as neutrophils, macrophages, lymphocytes and eosinophils in the BALF of the asthmatic group, when compared with normal group of mice. However, treatment with cavidine decreased the number of neutrophils $\left(1.82 \times 10^{5}\right)$, lymphocytes $\left(3.91 \times 10^{5}\right)$, eosinophils $\left(1.84 \times 10^{5}\right)$ and macrophages $\left(7.48 \times 10^{5}\right)$ in BALF, relative to untreated asthmatic group of mice.

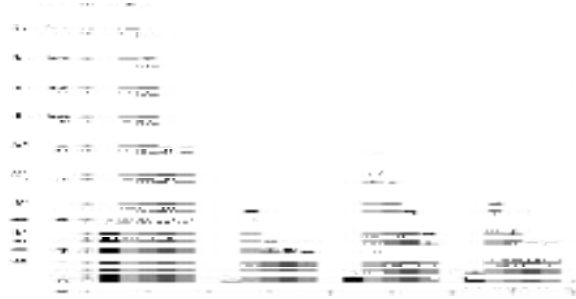

Figure 1: Effect of cavidine on inflammatory cells in OVA-sensitized mice. Data are mean \pm SEM $(n=10)$; ${ }^{\# \#} p<0.01$ vs normal group; ${ }^{*} p<0.05,{ }^{* *} p<0.01$ vs. asthmatic group

\section{Cavidine attenuated altered levels of OVA- specific IgEand TGF- $\beta 1$}

The effect of cavidine was observed on the OVAspecific $\lg E$ and TGF- $\beta 1$ in OVA-sensitized mice. There were increases in the number of OVA-specific IgE up to $157 \mathrm{ng} / \mathrm{ml}$, and TGF- $\beta 1$ up to $310 \mathrm{pg} / \mathrm{ml}$ in the asthmatic group. However, cavidine significantly $(p<0.01)$ decreased OVAspecific IgE (83 ng/mL) and TGF- $\beta$ 1 (127 $\mathrm{pg} / \mathrm{mL}$ ), when compared with the asthmatic group (Figure 2).

\section{Cavidine attenuated the altered level of cytokines}

Effect of cavidine was determined on the concentration of cytokines in the BALF of mice sensitized with OVA. There were significant increases in levels of IL-17, IL-13, IL-6 and IL-4, while INFy level was significantly reduced $(p<$ 0.01 ) in the asthmatic group, when compared to the normal group. Thus, cavidine ameliorated the altered levels of cytokines in OVA-sensitized mice. These results are shown in Figure 3.

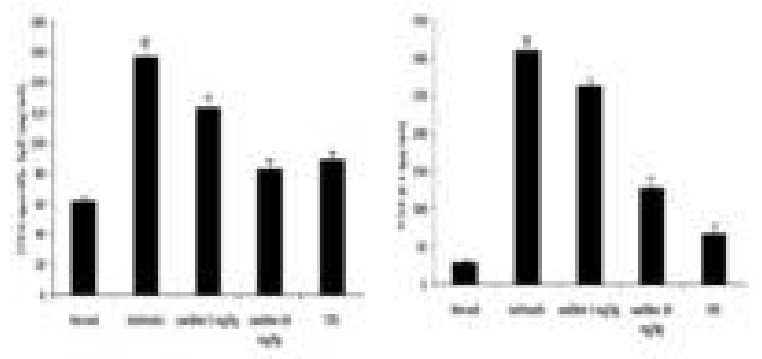

Figure 2: Cavidine attenuated OVA-specific $\lg \mathrm{E}$ and TGF- $\beta$ 1in OVA-sensitized mice. Data are mean \pm SEM ( $\mathrm{n}=10)$; ${ }^{\# \#} p<0.01$ vs. normal group; ${ }^{*} p<0.05$, ${ }^{* *} p<0.01$ vs. asthmatic group

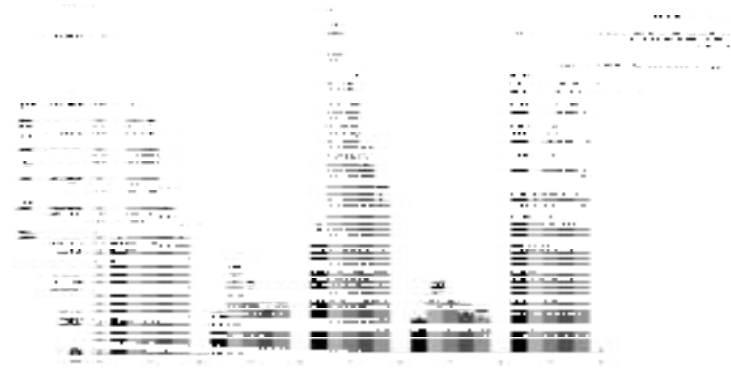

Figure 3: Effect of cavidine on cytokine levels in OVAsensitized mice. Data are mean \pm SEM $(n=10) ;{ }^{\# \#} p<$ 0.01 vs. normal group; ${ }^{*} p<0.05,{ }^{* \star} p<0.01$ vs. asthmatic group

\section{Cavidine attenuated inflammatory scores in OVA-sensitized mice}

Lung architecture was assessed histopathological using H\&E staining. As depicted in Figure 4 , the peribronchiolar and perivascular tissues of the OVA-challenged group contained inflammatory cells. However, the cavidine group showed reduction in the inflammatory cells in lung tissues. Moreover, inflammatory score was higher in the lung tissues of the asthmatic group than in normal group. However, treatment with cavidine and Dex significantly $(p<0.01)$ reduced the inflammatory score in in the lung tissues, relative to that in asthmatic mice.

\section{Cavidine attenuated NF-KB activity in OVA- sensitized mice}

Figure 5 shows that the levels of $p-N F-k B$ p65, $\mathrm{NF}-\mathrm{kB}$ p65 and $\mathrm{p}-\mathrm{I} \mathrm{kB} \alpha$ increased significantly in tissue homogenates of the asthmatic group, relative to the normal group. However, levels of $\mathrm{p}-\mathrm{I} \mathrm{KB} \alpha, \mathrm{p}-\mathrm{NF}-\mathrm{kB} \mathrm{p} 65$ and NF-kB p65 proteins were significantly and dose-dependently 
downregulated in the cavidine groups, when compared to the asthmatic group $(p<0.01)$.
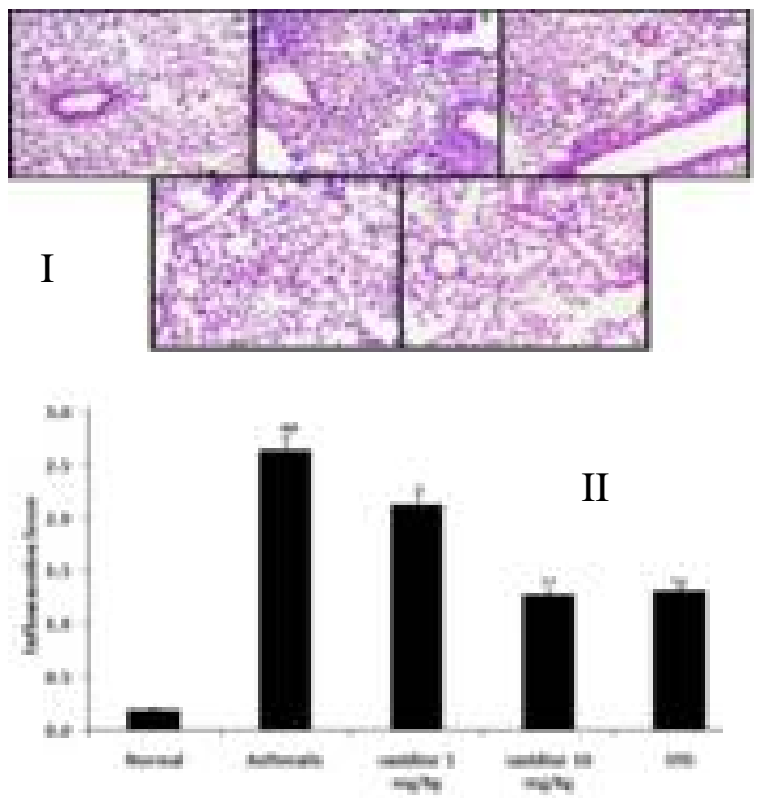

Figure 4: Effect of cavidine on the histopathology of lung of OVA-sensitized mice. I: Histopathology of lung (A: normal; B: asthmatic; C: cavidine $5 \mathrm{mg} / \mathrm{kg}$; D: cavidine $10 \mathrm{mg} / \mathrm{kg}$; E: STD); II: Inflammatory score. Data are mean \pm SEM $(\mathrm{n}=10) ;{ }^{\# \#} p<0.01$ vs normal group; ${ }^{*} p<0.05,{ }^{* *} p<0.01$ vs asthmatic group

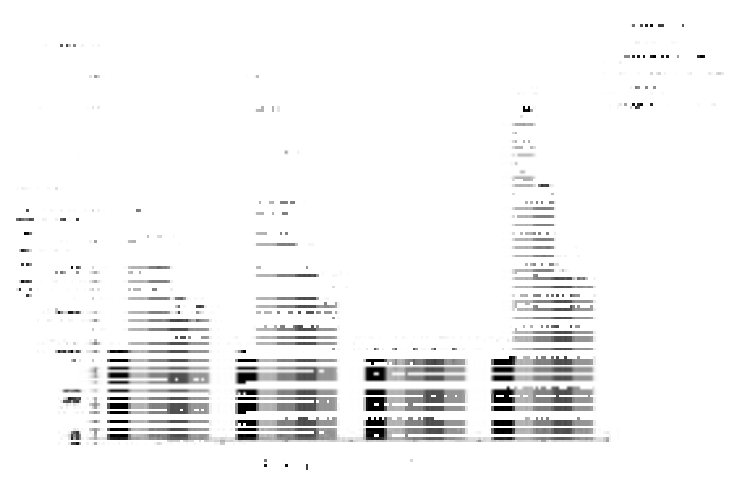

Figure 5: Effect of cavidine on the levels of $p-N F-k B$ $\mathrm{p} 65, \mathrm{NF}-\mathrm{kB} \mathrm{p} 65, \mathrm{p}$-I $\mathrm{kB \alpha}$ and IKBa proteins in OVAsensitized mice. Data are mean \pm SEM $(n=10) ;{ }^{\# \#} p<$ 0.01 vs. normal group; ${ }^{*} p<0.05,{ }^{* *} p<0.01$ vs. asthmatic group

\section{Cavidine attenuated the expressions of PTEN mTORc1, p-Akt and Akt}

The effect of cavidine on the expressions of PTEN, mTORc1, p-Akt and Akt proteins in tissue homogenate of OVA sensitized mice is shown in Figure 6. There was enhancement in the relative expression of mTORc1, p-Akt and Akt proteins, and reduction in the expression of PTEN protein in the tissue homogenate of the asthmatic group, relative to the normal group. However, treatment with cavidine ameliorated the altered expressions of PTEN, mTORc1, Akt and p-Akt proteins in tissue homogenates of OVA-sensitized mice.
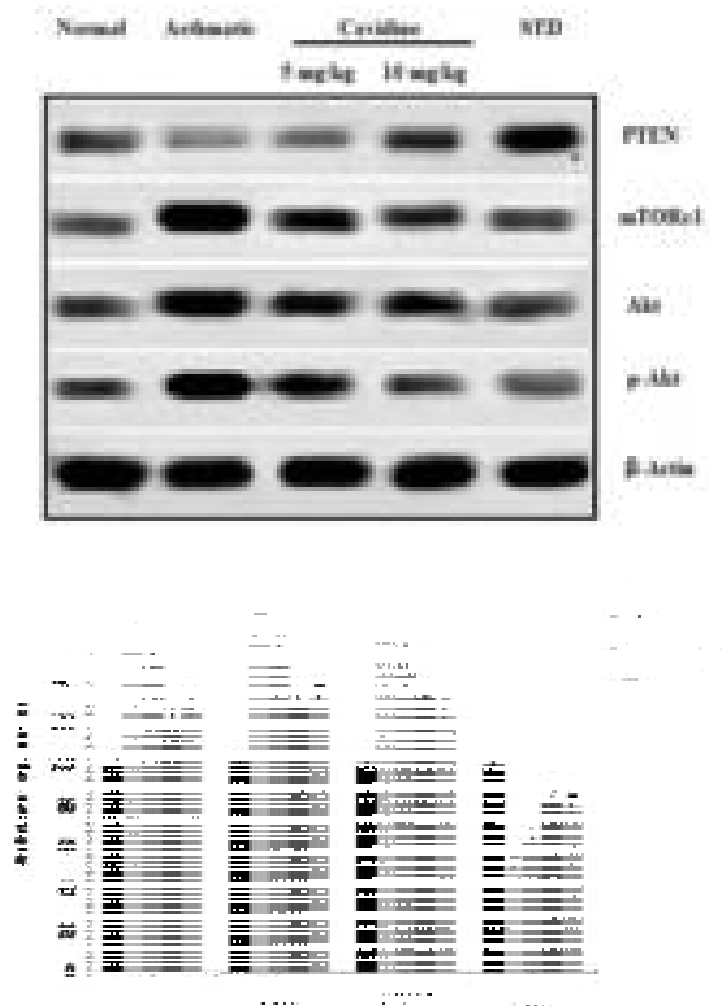

Figure 6: Effect of cavidine on the expressions of PTEN, mTORc1, Akt and p-Akt proteins in tissue homogenate of OVA-sensitized mice. Data are mean \pm SEM $(\mathrm{n}=10):{ }^{\#} p<0.01$ vs. normal group; ${ }^{*} p<0.05$, ${ }^{* *} p<0.01$ vs. asthmatic group

\section{DISCUSSION}

The prevalence of asthma has increased in the recent years. Anti-inflammatory therapies such as steroids are often used in the management of asthma but many limitations are associated with it. Thus, there is a need for alternative medicine for the management of asthma. The present investigation evaluated the anti-asthmatic effect of cavidine in neonatal mice through determination of the number of inflammatory cells and cytokine levels in BALF, and OVAspecific IgE, and TGF- $\beta$ in the serum of OVAsensitized mice. Moreover, histopathology, NF$\mathrm{kB}$ level, and expression of PI3K signaling protein were determined in the lung tissues of the OVA-sensitized mice.

The development of asthma is marked by infiltration of inflammatory cells in lung tissue [14]. Thus, drugs used for the management of asthma function by reducing the number of inflammatory cells [15]. The results of the present investigation showed that cavidine treatment attenuated the number of inflammatory cells in 
OVA-sensitized mice. Cytokines also play an important role in the pathogenesis of asthma [16]. This study has shown that treatment with cavidine significantly ameliorated the cytokine levels in BALF of OVA-sensitized mice.

The proliferation and initiation of CD4+ $\mathrm{T}$ cells occur due to PI3K signaling which is regulated by several proteins such as PTEN, mTORc1, p-Akt and Akt [17]. The proliferation of CD4+ T cells contributes to the development of asthma [18]. Cavidine attenuated the expressions of PTEN, mTORc1, p-Akt and Akt protein in the lung tissues of OVA-sensitized mice. The NF-KB signaling pathway contributes to the pathogenesis of asthma by regulating immunity and inflammation. Studies have shown that the expression of NF-KB is increased in the lung tissues of asthmatic patients [19]. The data obtained in the investigation reveals that cavidine significantly reduced the expression of NF-KB in OVA-sensitized mice, relative to untreated asthmatic mice.

\section{CONCLUSION}

These results reveal that the anti-asthma activity of cavidine in OVA-induced asthma in neonatal mice occurs through attenuation of lung tissue inflammation and immune responsive cells. Thus, cavidine may be clinically effective in the management of asthma.

\section{DECLARATIONS}

\section{Acknowledgement}

All the authors of this manuscript are thankful to Medical College of Yan'an University, China for providing the necessary facilities for the presented work.

\section{Conflict of interest}

No conflict of interest is associated with this work.

\section{Contribution of authors}

We declare that this work was done by the authors named in this article and all liabilities pertaining to claims relating to the content of this article will be borne by the authors. Qin Hao performed the experimental work and literature survey. Juan Shen had done histopathology and statistical analysis and Lin Zhao supervised and wrote the manuscript.

\section{REFERENCES}

1. Robb CT, Regan KH, Dorward DA, Rossi AG. Key mechanisms governing resolution of lung inflammation. Semin Immunopathol. 2016; 38(4): 425 - 448.

2. Evans CM, Kim K, Tuvim MJ, Dickey BF. Mucus hypersecretion in asthma: causes and effects. Cur opin in pulmona medicin. 2009; 15(1): 4 - 11.

3. Murdoch JR, Lloyd CM. Chronic inflammation and asthma. Mutat Res 2010; 690(1-2): 24 - 39.

4. Galli SJ, Tsai M. IgE and mast cells in allergic disease. Nat Med. 2012; 18(5): 693 - 704.

5. Basson MA. Signaling in Cell Differentiation and Morphogenesis. Cold Spring Harb Perspect Biol. 2012; 4(6): a008151.

6. Hassan B, Akcakanat A, Holder AM, Meric-Bernstam F. Targeting the PI3-kinase/Akt/mTOR Signaling Pathway. Surg Oncol Clin N Am. 2013; 22(4): 10.1016/j.soc.2013.06.008.

7. Herrero-Sánchez MC, Rodríguez-Serrano C, Almeida J, et al. Targeting of PI3K/AKT/mTOR pathway to inhibit $T$ cell activation and prevent graft-versus-host disease development. J Hematol Oncol. 2016; 9: 113.

8. Niu X, Liu F, Li W, Zhi W, Zhang H, Wang X, He Z., Cavidine Ameliorates Lipopolysaccharide-Induced Acute Lung Injury via NF-KB Signaling Pathway in vivo and in vitro. Inflammation. 2017; 40(4): 1111-1122.

9. Li W1, Huang $H$, Zhang $Y$, Fan T, Liu X, Xing W, Niu X. Anti-inflammatory effect of tetrahydrocoptisine from Corydalis impatiens is a function of possible inhibition of TNF- $\alpha$, IL-6 and NO production in lipopolysaccharidestimulated peritoneal macrophages through inhibiting NF-KB activation and MAPK pathway. Eur $J$ Pharmacol. 2013 5; 715(1-3): 62-71.

10. Li W, Wang X, Zhang H, He Z, Zhi W, Liu F, Wang Y, Niu $X$. Anti-ulcerogenic effect of cavidine against ethanolinduced acute gastric ulcer in mice and possible underlying mechanism. Int Immunopharmacol. 2016; 38: 450-459.

11. Niu $X$, Zhang $H$, Li W, Mu Q, Yao H, Wang Y., Antiinflammatory effects of cavidine in vitro and in vivo, a selective COX-2 inhibitor in LPS-induced peritoneal macrophages of mouse. Inflammation. 2015; 38: 923933.

12. Niu $X$, Zhang $H$, Li W, Wang $Y, M u Q$, Wang $X$, He $Z$, Yao $H$. Protective effect of cavidine on acetic acidinduced murine colitis via regulating antioxidant, cytokine profile and NF-KB signal transduction pathways. Chem Biol Interact. 2015; 239: 34-45.

13. Guide for the Care and Use of Laboratory Animals: Eighth Edition Committee for the Update of the Guide for the Care and Use of Laboratory Animals; National Research Council. 2010; ISBN: 0-309-15401-4.

14. Durrant DM, Gaffen SL, Riesenfeld EP, Irvin CG, Metzger DW. Development of Allergen-induced Airway Inflammation in the Absence of T-bet Regulation is Dependent on IL-17. Journal of immunology (Baltimore, Md: 1950). 2009; 183: 5293-5300.

Trop J Pharm Res, March 2019; 18(3):517 
15. Zdanowicz MM. Pharmacotherapy of Asthma. Am J Pharm Educ. 2007; 71: 98.

16. Kips JC., Cytokines in asthma. Eur Respir J Suppl. 2001; 34: $24 s-33 s$.

17. Limon JJ, Fruman DA. Akt and mTOR in B Cell Activation and Differentiation. Front Immunol. 2012; 3: 228.
18. Ling MF, Luster AD. Allergen-Specific CD4+ T Cells in Human Asthma. Ann Am Thorac Soc. 2016; 13(Suppl 1): $S 25-S 30$.

19. Zhou Y, Wang GF, Yang L, et al. Treatment with 1, $25(\mathrm{OH})_{2} \mathrm{D}_{3}$ induced $\mathrm{HDAC2}$ expression and reduced NF$\kappa B$ p65 expression in a rat model of OVA-induced asthma. Braz J Med Biol Res. 2015; 48: 654-664. 